Gut, 1986, 27, 399-404

\title{
Enhanced synthesis of cholesterol and its precursors in jejunal mucosa in coeliac disease
}

\author{
M VUORISTO AND T A MIETTINEN \\ From the Second Department of Medicine, University of Helsinki, Helsinki, Finland
}

SUMmaRY Patients with coeliac disease have a greatly enhanced whole body synthesis of cholesterol, but its origin is not known. In this paper the synthesis and concentrations of cholesterol and its precursors, squalene and methyl sterols, were studied in jejunal biopsies from healthy volunteers and adult patients with coeliac disease. The incorporation rates of ${ }^{14} \mathrm{C}$-acetate and ${ }^{3} \mathrm{H}$-mevalonate into non-saponifiable lipids (sum of squalene, methyl sterols and cholesterol) were increased 14 and six times in the damaged mucosa, respectively. The cyclisation rate of mucosal squalene and the conversion of squalene to cholesterol were also increased, indicating that cholesterol synthesis was activated before mevalonate, probably at the step of HMG-CoA reductase, and also after mevalonate and squalene. The steps from squalene to cholesterol were apparently not rate limiting because the mucosal concentrations and the percentage distribution of squalene and sterols were similar in the patients and in the controls. A positive correlation of the cholesterol synthesis with the number of crypt cells, suggests that the expanded crypt cell population contributed to the enhanced intestinal cholesterologenesis. Furthermore, the serum cholesterol level was negatively correlated with the ${ }^{14} \mathrm{C}$ - and ${ }^{3} \mathrm{H}$-counts in the mucosal cholesterol and with the cyclisation rate of squalene probable signs of regulatory role of serum low density lipoprotein cholesterol in intestinal cholesterol synthesis. Consequently, provided that the synthesis of musocal cholesterol is as high in vivo as in vitro it could contribute to the highly increased overall synthesis of cholesterol in the patients with coeliac disease.

Previous studies have shown that the whole body synthesis of cholesterol in patients with coeliac disease is greatly enhanced. ${ }^{2}$ The liver and the small intestine are most likely the sites of the increased cholesterol synthesis because available data indicate that these organs have the most active cholesterogenesis in the body. ${ }^{34}$

At present no direct measurements of hepatic cholesterol synthesis exist in coeliac disease. The recent data on lipoprotein metabolism in coeliac disease, however, indicate that the synthesis in the liver may not be markedly increased because the production rates of very low density lipoprotein and low density lipoprotein and the receptor mediated catabolism of low density lipoprotein are low. ${ }^{5}$ Also low serum concentrations of methylated cholesterol precursor sterols ${ }^{6}$ indicate that the hepatic synthesis of cholesterol may not be dramatically enhanced in coeliac disease. On the other hand, the previous

Address for correspondence: Professor Tatu A Miettinen, Second Department of Medicine, University of Helsinki, (0)290) Helsinki 29, Finland.

Received for publication 5 July 1985 . study of Dietschy and $\mathrm{Gamel}^{3}$ on four patients with idiopathic steatorrhea showed an enhanced incorporation of ${ }^{14} \mathrm{C}$-acetate to cholesterol in jejunal biopsies. Consequently, an increased intestinal cholesterologenesis may contribute to the high overall cholesterol synthesis in coeliac disease. To explore this alternative further, we have compared the synthesis of cholesterol and its precursors, squalene and methyl sterols and their mucosal concentrations in jejunal biopsies of healthy subjects and patients with established coeliac disease.

\section{Methods}

PATIENTS AND BIOPSY PROCEDURES

The studies were carried out in biopsies of seven volunteers and in 14 routine biopsies for diagnosis of suspected coeliac disease (Table 1). They consumed normal home diet and used no drugs. A single jejunal biopsy was taken after an overnight fast with Bult's capsule (Carl Storz, West Germany). It was positioned just past the ligament of Treitz, under a fluoroscopic control. Thereafter, the capsule was 
Table 1 Clinical and laboratory data of the control subjects and the patients with coeliac disease. Mean \pm SEM are given.

\begin{tabular}{|c|c|c|c|c|c|}
\hline Subjects & $\begin{array}{l}\text { Sex* } \\
F / M\end{array}$ & $\begin{array}{l}\text { Age } \\
(y r)\end{array}$ & $\begin{array}{l}\text { Relative } \dagger \\
\text { body } \\
\text { weight }\end{array}$ & $\begin{array}{l}\text { Serum } \\
\text { cholesterol, } \\
\text { mmol/l }\end{array}$ & $\begin{array}{l}\text { Faecal } \\
\text { fat, } \\
\text { g/day }\end{array}$ \\
\hline Controls & $5 / 2$ & $40 \pm 3$ & $1.08 \pm 0.06$ & $6 \cdot 5 \pm 0 \cdot 3$ & $4 \cdot 5 \pm 1 \cdot 1$ \\
\hline Patients & $9 / 5$ & $36 \pm 3$ & $1 \cdot 01 \pm 0.03$ & $5 \cdot 9 \pm 0 \cdot 5$ & $9 \cdot 6 \pm 2 \cdot 7 \ddagger$ \\
\hline
\end{tabular}

${ }^{*} \mathrm{~F}=$ female, $\mathrm{M}=$ male. †Ideal body weight is expressed as 1.00 . $\ddagger \mathrm{n}=9$.

immediately withdrawn and the specimen was divided into two parts. The one specimen was fixed with $10 \%$ formalin, embedded into paraffin, cut into $5 \mu \mathrm{m}$ thick slices and stained with haematoxylin and eosin for the light microscopic examination. The other specimen was quickly placed into a vessel containing $0.9 \%$ saline, blotted with filter paper, weighed and transferred into the buffer for incubation.

\section{HISTOLOGICAL PROCEDURES}

The villous height was measured from the tip of the villus to the junction of the villus and the crypt. On an average of four adjacent villi were measured. A specimen with villous height $300 \mu \mathrm{m}$ or over was regarded as a normal mucosa. For counting of the number of epithelial cells a grid was used. Its lower margin was adjusted in the middle of the muscularis mucosae and the left margin in the centre of the crypt. Empty squares in the grid were taken further from the right margin in order to calculate a tissue volume of $12.5 \times 10^{3} \mu \mathrm{m}^{3}$. The distribution of crypt and villous cells was obtained by calculating in each crypt the right side up to the crypt villus junction and further up to the tip of villus on an average of three adjacent villi.

\section{INCUBATIONS}

The biopsy specimens of the controls and the patients used for incubation studies weighed $13.0+2.1 \mathrm{mg}$ and $11.5 \pm 1.8 \mathrm{mg}$ (mean \pm SEM), respectively. They were incubated in $2.0 \mathrm{ml}$ KrebsRinger bicarbonate buffer containing $4 \%$ bovine albumin (Fraction V, Armour Pharmaceutical Company, England). The $\mathrm{pH}$ was adjusted to 7.4 by gassing the medium continuously with $95 \% \mathrm{O}_{2}$ and $5 \% \mathrm{CO}_{2}$. After preincubation for five min $6 \mu \mathrm{Ci}$ of both ${ }^{14} \mathrm{C}$-acetate (specific activity $2.9 \mathrm{mCi} / \mathrm{mg}$ ) and ${ }^{3} \mathrm{H}$-mevalonate (specific activity $2.9 \mathrm{mCi} / \mathrm{mg}$ ) with unlabelled acetate and mevalonate were added into the incubation medium to get a final concentration of $0.5 \mathrm{mmol} / \mathrm{l}$ for both substrates. The incubation was continued at $37^{\circ} \mathrm{C}$ up to three hours with shaking (100 oscillations/min).

\section{CHEMICAL METHODS}

After incubation the specimens were washed five times with physiological saline, homogenised and after addition of coprostanol for an internal standard, lipids were extracted with choloroformmethanol (2:1). ${ }^{7}$ After removal of the lower phase the remainder was evaporated to dryness, dissolved in $0.1 \mathrm{~N} \mathrm{NaOH}$ and the protein content was determined according to Lowry et al. ${ }^{8}$ The lower phase was washed three times with the pure solvent upper phase to remove the non-lipid radioactivity. After evaporation of the choloroform phase with a nitrogen stream, the extract was saponified with $10 \mathrm{~N} \mathrm{NaOH}$-absolute ethanol (1:9) for one hour at $80^{\circ} \mathrm{C}$. Non-saponifiable lipids were extracted with petroleum ether and analysed with a thin layer chromatographic - gas liquid chromatographic method. ${ }^{9}$ The radioactivities were measured with a Packard Tri-Carb liquid scintillation spectrometer (model 3003, Packard Instrument Company, USA) at $4^{\circ} \mathrm{C}$ in $18 \mathrm{ml}$ toluene containing $3 \mathrm{~g} / 1$ of $2,5-$ diphenyloxazole (PPO) and $0.3 \mathrm{~g} / 1$ of p-bis-2-(5phenyl-oxazyl)-benzene (POPOP) in toluene. An external standard was used to get the absolute levels of radioactivity. Serum cholesterol was measured according to the method of Huang et al, ${ }^{10}$ and faecal fat as described by van de Kamer et al. ${ }^{11}$

\section{CALCULATIONS}

Incorporation rates of ${ }^{3} \mathrm{H}$-mevalonate (in terms of $\mu \mathrm{g} / 100 \mathrm{mg}$ protein/three hours) into squalene and sterols were calculated by dividing the radioactivity of squalene and sterols by the specific activity of the substrate in the incubation medium. The ${ }^{3} \mathrm{H}$-radioactivities were multiplied by 2 because a racemate form of mevalonate was used. To correct the loss of radioactivity $(33 \%)$ in different demethylations the radioactivity of ${ }^{3} \mathrm{H}$-cholesterol was multiplied by $1 \cdot 5 .{ }^{12}$ Because the synthesis of squalene consists of 6 mevalonic acids the synthesis rate of squalene was calculated by dividing the incorporation rates of mevalonate into squalene and sterols by a factor 6 . The combined synthesis rate of methyl sterols plus cholesterol from ${ }^{3} \mathrm{H}$-mevalonate was regarded as the cyclisation rate of squalene. Relative body weight was calculated from the data of Metropolitan Life Insurance Company. ${ }^{13}$

The statistical significance was calculated with Student's $t$ test. Means \pm SEM are given in the text.

\section{Results}

Clinical picture and laboratory parameters (Table 1) 
indicated that the disease was moderately severe. The villous height was markedly reduced and the number of epithelial cells was significantly decreased in the intestinal mucosa of the coeliac patients $\left(438 \pm 81\right.$ vs $561 \pm 73$ cell $\times 10^{3} / \mathrm{mm}^{3}$ in the controls, $p<0.005)$, while the protein contents were not significantly different $(47 \cdot 1 \pm 5 \cdot 2$ vs $61 \cdot 6 \pm 15 \cdot 7$ $\mu \mathrm{g} / \mathrm{mg}$ ). The epithelial cell count/ $\mu \mathrm{g}$ of tissue protein was quite similar in the two groups $\left(9.3 \times 10^{3} \mathrm{vs}\right.$ $\left.9 \cdot 1 \times 10^{3}\right)$. In the patients, however, the villous height and the number of villous cells were low and the number of crypt cells high, so that the ratio villous cell/crypt cell was markedly lower in the jejunal mucosa from the patients than the controls (Table 2).

The respective radioactivities of ${ }^{14} \mathrm{C}$ and ${ }^{3} \mathrm{H}$ recovered in non-saponifiable lipids (sum of squalene, methyl sterols and cholesterol) after incubation of mucosal biopsies with a mixture of ${ }^{14} \mathrm{C}$-acetate and ${ }^{3} \mathrm{H}$-mevalonate were 14 and six times higher in the patients than in the controls (Table 3). Thus, the mucosal cholesterol synthesis was activated both before and after the mevalonate step in the patients. The cyclisation rate of squalene was four times higher in the patients than in the controls indicating that also the postsqualene steps were enhanced in the damaged mucosa (Table 4).

The relative distribution of the ${ }^{14} \mathrm{C}$ - and ${ }^{3} \mathrm{H}$ radioactivities between mucosal squalene, methyl sterols and cholesterol showed that the proportion of the labels remaining in squalene was significantly lower, that in methyl sterols similar and that in cholesterol markedly higher in the patients than in the controls (Table 3). In addition, the mucosal precursor concentrations were similar (Table 5) in the two groups. The findings suggest that also the demethylation and double bond rearrangement of lanosterol and other methyl sterols were markedly accelerated in the diseased mucosa. The ${ }^{14} \mathrm{C} /{ }^{3} \mathrm{H}$ ratios in squalene and sterols were, however, only two-fold increased in the patients as compared with the controls (Table 3).

To disclose possible reasons for the increased synthesis activity of cholesterol in the diseased mucosa several correlations were calculated. The proportions of ${ }^{14} \mathrm{C}$ - and ${ }^{3} \mathrm{H}$-counts in mucosal cholesterol were negatively correlated with the villous cell/crypt cell ratio $(r=-0.58 ; p<0.05$ and

Table 3 Distribution of radioactivities between squalene and sterols in jejunal mucosal pieces on incubation with a mixture of ${ }^{14} \mathrm{C}$-acetate and ${ }^{3} \mathrm{H}$-mevalonate. Means $\pm S E M$.

\begin{tabular}{|c|c|c|c|}
\hline Parameter & $\begin{array}{l}\text { Controls } \\
(n=7)\end{array}$ & $\begin{array}{l}\text { Patients } \\
(n=14)\end{array}$ & $\begin{array}{l}\text { Activation } \\
\text { of } \\
\text { synthesis* }\end{array}$ \\
\hline \multicolumn{4}{|l|}{${ }^{14} \mathrm{C}$-radioactivity: } \\
\hline $\begin{array}{l}\mathrm{NSL}, \mathrm{DPM} / 100 \mathrm{mg} \\
\text { prot. } / 3 \mathrm{~h}: \\
\% \text { of } \mathrm{NSL}:\end{array}$ & $180 \cdot 5 \pm 57 \cdot 7$ & $2661 \cdot 8 \pm 629 \cdot 5^{*}$ & $14 \cdot 8$ \\
\hline Squalene & $53 \cdot 2 \pm 4 \cdot 9$ & $34 \cdot 9 \pm 5 \cdot 3^{*}$ & 9.7 \\
\hline Methyl sterols & $27 \cdot 3 \pm 4 \cdot 4$ & $22 \cdot 6 \pm 1 \cdot 0$ & $12 \cdot 3$ \\
\hline Cholesterol & $19 \cdot 5 \pm 2 \cdot 4$ & $42 \cdot 4 \pm 5 \cdot 6 * *$ & $40 \cdot 3$ \\
\hline Total NSL & 100 & 100 & \\
\hline \multicolumn{4}{|l|}{${ }^{3} \mathrm{H}$-radioactivity: } \\
\hline \multicolumn{4}{|l|}{$\mathrm{NSL}, \mathrm{DPM} / 100 \mathrm{mg}$} \\
\hline$\%$ of NSL: & & & \\
\hline Squalene & $77 \cdot 8 \pm 4 \cdot 1$ & $59 \cdot 9 \pm 4 \cdot 9^{*}$ & 4.4 \\
\hline Methyl sterols & $16 \cdot 7 \pm 3 \cdot 1$ & $19 \cdot 3 \pm 1 \cdot 8$ & $7 \cdot 4$ \\
\hline Cholesterol & $5 \cdot 6 \pm 1 \cdot 1$ & $20 \cdot 8 \pm 3 \cdot 1^{* *}$ & $24 \cdot 0$ \\
\hline Total NSL & 100 & 100 & \\
\hline \multicolumn{4}{|l|}{${ }^{14} \mathrm{C} /{ }^{3} \mathrm{H}$-ratio: } \\
\hline Squalene & $11 \cdot 1$ & $22 \cdot 2$ & $2 \cdot 0$ \\
\hline Methyl sterols & $25 \cdot 2$ & $46 \cdot 6$ & 1.8 \\
\hline Cholesterol & $56 \cdot 3$ & 100 & 1.8 \\
\hline
\end{tabular}

NSL =nonsaponifiable lipids; \#DPM in patients/DPM in controls ${ }^{*} \mathrm{p}<0 \cdot 05,{ }^{* *} \mathrm{p}<0 \cdot 01$; compared with control values.

${ }^{14} \mathrm{C} /{ }^{3} \mathrm{H}$ ratio indicated by 100 in cholesterol of NSL to which another ratio is related.
Table 2 Villous height and the relative distribution of epithelial cells in the villi in jejunal mucosal pieces from seven control subjects and 14 patients with coeliac disease. Mean $\pm S E M$

\begin{tabular}{lcll}
\hline Parameter & Controls & Patients & p-value \\
\hline Villous height, $\mu \mathrm{m}$ & $478 \pm 27$ & $168 \pm 23$ & $<0.001$ \\
Villous cells & $190 \pm 11$ & $112 \pm 15$ & $<0.005$ \\
crypt cells & $63 \pm 5$ & $103 \pm 9$ & $<0.01$ \\
$\begin{array}{l}\text { Villous cell/crypt } \\
\text { cell-ratio (no) }\end{array}$ & $3 \cdot 1 \pm 0.2$ & $1.3 \pm 0.2$ & $<0.001$ \\
\hline
\end{tabular}

${ }^{*}$ Cell $/ \mu \mathrm{m}^{3}$
Table 4 Cyclisation rate of squalene* in jejunal mucosal specimens on incubation with mixture of ${ }^{14} \mathrm{C}$-acetate and ${ }^{3}$ H-mevalonate. Mean $\pm S E M$.

\begin{tabular}{|c|c|c|}
\hline Parameter & $\begin{array}{l}\text { Controls } \\
(n=6)\end{array}$ & $\begin{array}{l}\text { Patients } \\
(n=7)\end{array}$ \\
\hline $\begin{array}{l}\text { Cyclisation rate of squalene: } \\
\mu \mathrm{g} / 100 \mathrm{mg} \text { prot. } / 3 \mathrm{~h} \\
\% \text { of squalene synthesis }\end{array}$ & $\begin{array}{r}4.6 \pm 1 \cdot 7 \\
21 \cdot 8 \pm 3 \cdot 9\end{array}$ & $\begin{array}{l}17 \cdot 0 \pm 3 \cdot 6 \dagger \\
39 \cdot 0 \pm 4 \cdot 5 \dagger\end{array}$ \\
\hline
\end{tabular}

*Cyclisation rate of squalene was calculated from the synthesis rate of ${ }^{3} \mathrm{H}$-sterols.

$\dagger \mathrm{p}<0.02$ from the respective control values. 
Table 5 Concentrations and the percentage distribution of squalene, methyl sterols and cholesterol in jejunal biopsies of seven control subjects and 14 patients with coeliac disease. Means $\pm S E M$.

\begin{tabular}{|c|c|c|c|c|}
\hline \multirow[b]{2}{*}{ Parameter } & \multicolumn{2}{|c|}{$\mu g / 100 \mathrm{mg}$ protein } & \multicolumn{2}{|c|}{$\%$ of total $^{*}$} \\
\hline & Controls & Patients & Controls & Patients \\
\hline $\begin{array}{l}\text { Squalene } \\
\text { Methyl sterols }\end{array}$ & $\begin{array}{l}309 \pm 105 \\
(n=6)\end{array}$ & $\begin{array}{c}353 \pm 58 \\
(n=7)\end{array}$ & $5 \cdot 1 \pm 1 \cdot 5$ & $7 \cdot 2 \pm 1 \cdot 7$ \\
\hline Total & $54 \pm 41$ & $96 \pm 25$ & $0 \cdot 9 \pm 0 \cdot 6$ & $2 \cdot 2 \pm 0.5$ \\
\hline I & $22 \cdot 4 \pm 17 \cdot 5$ & $53 \cdot() \pm 14 \cdot 7$ & $39 \cdot 6 \pm 2 \cdot 2$ & $52 \cdot 3 \pm 4 \cdot 6$ \\
\hline II & $0 \cdot 4 \pm 0 \cdot 3$ & $0 \cdot 6 \pm 0 \cdot 5$ & $2 \cdot 9 \pm 2 \cdot 2$ & $1 \cdot 3 \pm 1 \cdot 3$ \\
\hline III & $1 \cdot 3 \pm 0 \cdot 4$ & $0.9 \pm 0 \cdot 3$ & $10 \cdot(0 \pm 3 \cdot 4$ & $1 \cdot 6 \pm 0.7$ \\
\hline IV & $20 \cdot 6 \pm 15 \cdot 7$ & $22 \cdot 9 \pm 4 \cdot 7$ & $38 \cdot 8 \pm 4 \cdot 1$ & $28 \cdot 5 \pm 4 \cdot 1$ \\
\hline V & $9 \cdot 5 \pm 8 \cdot 8$ & $18 \cdot 2 \pm 6 \cdot 3$ & $8 \cdot 7 \pm 2 \cdot 4$ & $16 \cdot 3 \pm 3 \cdot 2$ \\
\hline Cholesterol & $3971 \pm 361$ & $4857 \pm 492$ & $94 \cdot() \pm 2 \cdot 0$ & $90 \cdot 6 \pm 2 \cdot 1$ \\
\hline Total & & & $100 \cdot 0$ & $100 \cdot 0$ \\
\hline
\end{tabular}

*The percentage distributions of squalene, total methyl sterols and cholesterol were calculated from six controls and seven patients only.

Composition of methyl sterol subfractions:

I 4-methyl-5-cholest-8-en-3-ol

II 4,4-dimethyl-5-cholest-8-en-3-ol

III 4-methyl-5-cholest-7-en-3-ol

IV 4,4,14-trimethyl-5-cholest-8,24-dien-3-ol

V 4,4-dimethyl-5-cholest-8,24-dien-3-ol

$r=-0 \cdot 71 ; p<0 \cdot 01$, respectively). Furthermore, the total radioactivity of ${ }^{14} \mathrm{C}$-acetate found in nonsaponifiable lipids was positively correlated with the number of crypt cells $(r=0 \cdot 70 ; p<0 \cdot 001)$, but negatively with the number of villous cells $(r=-0.46$; $\mathrm{p}<0.05)$ and the villous height $(\mathrm{r}=-0.51 ; \mathrm{p}<0.05)$. Thus, the high synthesis rate of cholesterol is closely related to the increased crypt cell population in the damaged mucosa. The serum cholesterol level was negatively correlated with the proportions of ${ }^{14} \mathrm{C}$ and ${ }^{3} \mathrm{H}$-counts in mucosal cholesterol $(r=-0.66$ and $r=-0.57 ; p<0.05$ for both), and the cyclisation rate of squalene $(r=-0.64 ; p<0 \cdot 05)$.

\section{Discussion}

The present results show that in the synthesis pathway of cholesterol the steps between acetate and mevalonate, between mevalonate and squalene, and squalene and cholesterol are markedly activated in the damaged jejunal mucosa from patients with coeliac disease. These findings confirm and extend the preliminary observations of enhanced intestinal cholesterol synthesis in coeliac disease. ${ }^{3} 14$

The activity of HMG-CoAR (3-hydroxy-3methylglutaryl coenzyme $A$ reductase) between acetate and mevalonate is considered as the rate limiting step in the synthesis of cholesterol. The activity of the postmevalonate steps is higher allowing a marked increase in acetate flow to cholesterol without enzyme activation. ${ }^{15}$ The present in vitro incubation studies suggest that the premevalonate step was activated 14 times and the postmevalonate steps six times in the damaged intestinal mucosa of the coeliac disease patients. This and the ${ }^{14} \mathrm{C} /{ }^{3} \mathrm{H}$ ratio in squalene and sterols would mean that the activation of HMG-CoAR was roughly twice higher than that of the postmevalonate steps. Despite markedly increased acetate flow to squalene and sterols the mucosal squalene and methyl sterol contents were not increased in the coeliac disease patients. This would mean that in vivo squalene cyclisation, and subsequent demethylation and rearrangement of double bonds of lanosterol are not rate limiting steps in cholesterol synthesis of the damaged mucosa. Unexpected is the observation ${ }^{16} 19$ that the accumulation of squalene formed in vitro from ${ }^{3} \mathrm{H}$ mevalonate is higher than that formed from ${ }^{14} \mathrm{C}$ acetate-derived ${ }^{14} \mathrm{C}$-mevalonate. This phenomenon is seen also in coeliac disease (Table 2) and results in the low ${ }^{14} \mathrm{C} /{ }^{3} \mathrm{H}$ ratio in squalene as compared with methyl sterols and especially to cholesterol.

Most of the patients had partial villous atrophy so that the enhanced intestinal synthesis of cholesterol could originate both from villous and crypt cells. Human small intestinal mucosa, consisting mainly of villous cells, responds to exclusion of bile acids ${ }^{3} 18$ and neomycin-induced cholesterol malabsorption ${ }^{19}$ by an enhanced cholesterol synthesis. Lacking or reduced luminal cholesterol and/or bile acid absorption by damaged villous cells may increase cholesterol synthesis also in coeliac disease. The present data show, however, that the enhanced intestinal synthesis is closely related to the increased crypt cell population. This view is also supported by several animal experiments, demonstrating a higher synthesis rate of cholesterol in crypt than villous cells, ${ }^{2022}$ even though opposite findings have also been reported. ${ }^{23}$ Furthermore, an enhanced activity of HMG-CoAR has been reported in jejunal mucosa of three patients with coeliac disease. ${ }^{24}$

At present, however, no data are available concerning the regulation of cholesterol synthesis of crypt cells in human small intestinal mucosa. In the present study serum cholesterol concentration was negatively correlated with the proportions of ${ }^{14} \mathrm{C}$ and ${ }^{3} \mathrm{H}$-counts in mucosal cholesterol and the cyclisation rate of squalene. Whether this means that the activity of HMG-CoAR in crypt cells is under regulation of serum cholesterol or low density lipoprotein level remains, however, hypothetical and needs further exploration. The low low density lipoprotein level in coeliac disease, caused primarily by impaired cholesterol absorption, ${ }^{25}$ could actually 
provide insufficient cholesterol to hepatocytes and crypt cells enhancing their cholesterol synthesis. In the rat small intestinal epithelium not only the low density lipoprotein-cholesterol uptake and the rate of cholesterol synthesis appear to be separate events, ${ }^{26}$ but also the regulation of cholesterol synthesis within the two cell types may be different. ${ }^{22}$

Although in the present study the activity of intestinal cholesterol synthesis was highly increased in the patients with coeliac disease, cholesterol was not accumulated into the mucosa. Three possibilities can be visualised for this phenomenon. The finding could represent normal cholesterol metabolism in human crypt cells. A rapid enterocyte turnover could increase synthesis and consumption of cholesterol when sloughed cells would increase the loss into the gut. Newly synthesised cholesterol could also be secreted as a constituent of intestinal lipoproteins into the circulation. In coeliac disease the mitotic activity and the cell production rate in jejunal mucosa are actually increased two to six fold. ${ }^{27} 28$ Also the previous observations indicate that the faecal excretion of mucosal cholesterol loss from the gut tends to be higher in the patients than in the controls ( 370 vs $198 \mathrm{mg} /$ day 29). Thus, provided that the synthesis of intestinal cholesterol is increased in coeliac disease as much in vivo as in vitro, a portion of it could be shunted into the circulation to balance for the highly increased biliary secretion of cholesterol in coeliac disease. ${ }^{29}$ At present, however, there is only some evidence that crypt cells are capable of synthesising apoproteins, ${ }^{30}$ which are obligatory for lipid transport into the circulation.

\section{References}

1 Miettinen TA. Intestinal and faecal bile acids in malabsorption. Lancet 1968; 2: 358.

2 Vuoristo M, Tarpila S, Miettinen TA. Serum lipids and fecal steroids in patients with celiac disease; effects of gluten-free diet and cholestyramine. Gastroenterology 1980; 78: 1518-25.

3 Dietschy JM, Gamel WG. Cholesterol synthesis in the intestine of man: regional differences and control mechanisms. J Clin Invest 1971; 50: 872-80.

4 Spady DK, Dietschy JM. Sterol synthesis in vivo in 18 tissues of the squirrel monkey, guinea pig, rabbit, hamster, and rat. J Lipid Res 1983; 24: 303-15.

5 Kesäniemi YA, Vuoristo M, Miettinen TA. Metabolism of very low density and low density lipoproteins in patients with coeliac disease. In: Carlson LA, Olsson AG, eds. Treatment of hyperlipoproteinemia. Proceedings of the 41st European Atherosclerosis Group Meeting, Stockholm. New York: Raven Press, 1984: 49-53.

6 Miettinen TA. New insights into cholesterol dynamics. Arch Surg 1978; 113: 45-9.
7 Folch J, Lees M, Stanley GHS. A simple method for the isolation and purification of total lipids from animal tissues. J Biol Chem 1957; 226: 497-509.

8 Lowry OH, Rosenbrough NJ, Farr AL, Randall RJ. Protein measurement with the folin phenol reagent. $J$ Biol Chem 1951; 193: 265-75.

9 Miettinen TA. Serum squalene and methyl sterols as indicators of cholesterol synthesis in vivo. Life Sci 1969; 8: $713-21$

10 Huang TC, Chen CP, Wefler V et al. A stable reagent for the Liebermann-Burchard reaction. Application to rapid serum cholesterol determination. Anal Chem 1961; 33: 1405-7.

11 Van de Kamer JH, ten Bokkel Huinink H, Weyers HA. Rapid method for determination of fat in feces. $J$ Biol Chem 1949; 177: 347-55.

12 Goad LS. Sterol biosynthesis, In: Goodwin TW, ed. Natural substances formed biologically from mevalonic acid. Academic Press: London, New York, 1970: 45.

13 Metropolitan Life Insurance Company. New weight standards for men and women. Stat Bull 1959; 40: 1 .

14 Vuoristo M, Miettinen TA. Synthesis of squalene, methyl sterols and cholesterol in jejunal biopsies of patients with coeliac disease. [Abstract] VI World Congress of Gastroenterology, Madrid 1978: 49.

15 Gould RG, Swyrud EA. Sites of control of hepatic cholesterol biosynthesis. J Lipid Res 1966; 7: 698-707.

16 Tilvis R, Miettinen TA. Effects of weight reduction on squalene, methyl sterols and cholesterol and on their synthesis in human adipose tissue. Eur J Clin Invest 1979; 9: 155-60.

17 Strandberg TE, Tilvis RS, Miettinen TA. Regulation of cholesterol synthesis in the jejunal absorptive villous cells of the rat. Scand J Gastroenterol 1983; 18: 1017-23

18 Betteridge DJ, Krone W, Middleton C, Galton DJ. Regulation of sterol synthesis in human intestinal mucosa. Eur J Clin Invest 1980; 10: 277-30.

19 Miettinen TA. Effects of probucol and neomycin. Verh Dtsch Ges Inn Med 1983; 89: 1338-42.

20 Dietschy JM, Siperstein MD. Cholesterol synthesis by the gastrointestinal tract: Localization and mechanisms of control. J Clin Invest 1965; 44: 1311-27.

21 Shakir KM, Sundaram SG, Margolis S. Lipid synthesis in isolated intestinal cells. J Lipid Res 1978; 19: 433-42.

22 Strandberg TE, Tilvis RS, Miettinen TA. Squalene and sterol synthesis in isolated small-intestinal cells of the rat. Scand J Gastroenterol 1981; 16: 801-10.

23 Merchant JL, Heller RA. 3-hydroxy-3-methylglutaryl coenzyme $A$ reductase in isolated villous and crypt cells of the rat ileum. J Lipid Res 1977; 18: 722-33.

24 Gebhard RL, Stone BG, Prigge WF. Intestinal cholesterol synthesis in man. [Abstract]. Gastroenterology 1980; 78: 1171.

25 Vuoristo M, Miettinen TA. Cholesterol absorption, elimination and synthesis in coeliac disease. Eur J Clin Invest 1982; 12: 285-91.

26 Stange EF, Dietschy JM. Cholesterol synthesis and low density lipoprotein uptake are regulated independently in rat small intestinal epithelium. Proc Natl Acad Sci USA 1983; 80: 5739-43. 
27 Padykula HA, Strauss EW, Landman AJ, Gardner FH. A morphologic and histochemical analysis of the human jejunal epithelium in nontropical sprue. Gastroenterology 1961; 40: 735-65.

28 Wright N, Watson A, Morley A, Appleton D, Marks J. Cell kinetics in flat (avillous) mucosa of human small intestine. Gut 1973; 14: 701-10.
29 Vuoristo M, Miettinen TA. Increased biliary lipid secretion in celiac disease. Gastroenterology 1984; 88: $134-42$.

30 Green PHR, Lefkowitch JH, Glickman RM, Riley JW, Quinet E, Blum CB. Apolipoprotein localization and quantitation in the human intestine. Gastroenterology 1982; 83: 1223-30. 